\title{
Relationship Between Loci Conferring Downy Mildew and Powdery Mildew Resistance in Melon Assessed by Quantitative Trait Loci Mapping
}

\author{
L. Perchepied, M. Bardin, C. Dogimont, and M. Pitrat
}

First, third, and fourth authors: Institut National de la Recherche Agronomique, Unité de Génétique et d'Amélioration des Fruits et Légumes, BP 94, 84143 Montfavet cedex, France; and second author: Institut National de la Recherche Agronomique, Station de Pathologie Végétale, BP 94, 84143 Montfavet cedex, France.

Accepted for publication 20 January 2005.

\begin{abstract}
Perchepied, L., Bardin, M., Dogimont, C., and Pitrat, M. 2005. Relationship between loci conferring downy mildew and powdery mildew resistance in melon assessed by quantitative trait loci mapping. Phytopathology 95:556-565.

Partial resistance to downy mildew (Pseudoperonospora cubensis) and complete resistance to powdery mildew (Podosphaera xanthii races 1, 2, 3 , and 5 and Golovinomyces cichoracearum race 1) were studied using a recombinant inbred line population between 'PI 124112' (resistant to both diseases) and 'Védrantais' (susceptible line). A genetic map of melon was constructed to tag these resistances with DNA markers. Natural and artificial inoculations of Pseudoperonospora cubensis were performed

plained between 12 to $38 \%$ of the phenotypic variation for Pseudoperonospora cubensis resistance. Eight other Pseudoperonospora cubensis resistance QTL were identified. Artificial inoculations were performed with several strains of four races of Podosphaera xanthii and one race of G. cichoracearum. Two independent major genes, PmV.1 and PmXII.1, were identified and shown to be involved in the simple resistance to powdery mildew. Three digenic epistatic interactions involving four loci were detected for two races of Podosphaera xanthii and one race of G. cichoracearum. Co-localization between PmV.1, resistance genes, and resistance genes homologues was observed. Linkage between the major resistance QTL to Pseudoperonospora cubensis, pcXII.1, and one of the two resistance genes to powdery mildew, PmXII.1, was demonstrated.
\end{abstract} and replicated in several locations. One major quantitative trait loci (QTL), pcXII.1, was consistently detected among the locations and ex-
Additional keywords: Cucumis melo, polygenic inheritance.
Many fungi can attack melon foliage. Most of them induce necrotic lesions on the leaves. Some of them, such as downy mildew can kill the plants even at the adult plant stage. Others, like powdery mildew, decrease photosynthetic activity and reduce yield and fruit quality.

Downy mildew, caused by the obligate pathogenetic oomycete Pseudoperonospora cubensis (Berk. and Curtis) Rostovzev, is a major disease on cucurbits in humid production areas. Six pathotypes can be distinguished based on host compatibilities between various isolates and different cucurbit taxa $(14,60)$. The pathotype 3 is highly compatible with Cucumis sativus and $C$. melo (vars. reticulatus, conomon, and acidulus). It was first recorded in France in the 1980s.

Powdery mildew is a limiting factor for the production of melon throughout the world (54). The two main causal agents of the disease usually reported are Golovinomyces cichoracearum (syn. Erysiphe cichoracearum DC. ex Merat) and Podosphaera xanthii (formerly identified as Sphaerotheca fuliginea (Schlechtend.:Fr.) Pollacci) (9). Studies have shown that Podosphaera xanthii is predominant in most countries $(42,62)$, but G. cichoracearum can cause disease in temperate zones $(36,43)$. In France, both species have been recorded, but Podosphaera xanthii is the species most commonly found (4). G. cichoracearum differs from Podosphaera xanthii at the conidial stage (size and shape of conidia, presence of fibrosin bodies) and at the sexual stage (number of asci and ascospores). They also differ in patho-

Corresponding author: M. Pitrat; E-mail address: Michel.Pitrat@avignon.inra.fr

DOI: 10.1094/PHYTO-95-0556

(C) 2005 The American Phytopathological Society genicity against certain cucurbit cultivars and sensitivity to some fungicides (10). On melon, seven races have been described for Podosphaera xanthii and two races for G. cichoracearum (5).

Currently, the principal method of controlling both diseases is the use of protective fungicides. Unfortunately, some fungicides have lost their efficiency due to the development of resistance by the fungi $(24,26,28)$. The use of genetically resistant melon lines is a safe alternative or a complement to chemical control of these diseases. Several sources of resistance against Pseudoperonospora cubensis $(47,56,59,61)$, Podosphaera xanthii $(7,13,27)$, and G. cichoracearum (49) have been identified. Most of this resistance was found in melon accessions from India, such as 'PI 124111' and 'PI 124112'. The breeding lines 'MR-1' and 'PI 124111F' derived from 'PI 124111' present a high level of nonspecific resistance to downy and powdery mildews $(12,57)$.

The inheritance of melon resistance to Pseudoperonospora cubensis has been studied in 'MR-1' and 'PI 124112'. Two incompletely dominant complementary genes $(P c-1$ and $P C-2)$ have been described in 'MR-1' (12,58). Two complementary genes $(P c-4$ and $P c-1$ or $P c-2)$ have been identified to control resistance in 'PI 124112' $(31,32)$. Recently, Taler et al. (55) assessed that resistance of 'PI 124111F' to Pseudoperonospora cubensis is controlled by two enzymatic resistance genes, Atl and $A t 2$, which could correspond to $P c-1$ and $P c-2$. However, Epinat and Pitrat $(18,19)$ have found an oligogenic and incompletely dominant control in 'MR-1' and 'PI 124112', with five and four genetic factors, respectively. Thus, the resistance may be under dior oligogenic control and is partially dominant.

Genes of resistance to powdery mildew in melon have been studied by several authors, but the inheritance is still confusing, except for 'PMR 45' which has only one dominant gene $(20,27)$. 
Indeed most of the genotypes of melon resistant to powdery mildews involve several genes $(39,48)$. The number of genes involved differ according to the study $(20,33)$ and to the strain used (40). Very few allelism tests have been made to assess if any of the genes are common between resistant genotypes. For instance, Kenigsbuch and Cohen (33) reported that 'PI 124112' possessed one dominant gene $(P m 5)$ for resistance to race 1 and one partially dominant gene $(\mathrm{Pm} 4)$ for resistance to race 2 of Podosphaera xanthii, while Epinat et al. (20) described one dominant gene $\left(P m-C^{2}\right)$ controlling the resistance to both races (races 1 and 2 'Europe'). In most cases, monogenic or digenic dominant control has been reported.

The advent of molecular markers enables us to identify the chromosomal regions involved in the variation of disease resistances. Several genetic linkage maps have been constructed in melon, but no quantitative trait loci (QTL) for downy mildew and powdery mildew resistances have been reported. In this paper, we report a genetic analysis of partial resistance to downy mildew using a recombinant inbred line (RIL) population derived from 'PI 124112' and using quantitative evaluations in field, greenhouse, and growth chamber under natural or artificial infection. We also analyzed the genetics underlying the resistance to five races of the powdery mildew fungi Podosphaera xanthii and G. cichoracearum. Knowledge about the inheritance of these resistances will lead to a more efficient breeding strategy for durable resistance.

\section{MATERIALS AND METHODS}

Fungal isolates. A Pseudoperonospora cubensis isolate of pathotype 3 isolated on melon in Southern France in 1989 was used. The technique of pathogen conservation was described by Blancard et al. (8). Inoculum was produced with the same method.

Monoconidial strains isolated from melon crops and representing four races of Podosphaera xanthii and one race of G. cichoracearum were used in this study. Strains of Podosphaera xanthii were conserved in liquid nitrogen prior to the study according to the method described by Nicot et al. (44). Race 1 of Podosphaera xanthii (strain Sm3) was isolated in Tunisia. Race 2 (strains Sm1 and Schp), race 3 (strain 00Sm39), and race 5 (strains 98Sm65, Sm103.1, Sm99.1, Sm47.6, and SR5) of Podosphaera xanthii and race 1 (strains Em1, Em12.1, Em14.6, and Em83.2) of G. cichoracearum were isolated in France. The strains were maintained in collection by subculturing on cotyledons of Lagenaria leucantha 'Minibottle'. Inoculum was produced on cotyledons of melon 'Védrantais' or L. leucantha 'Minibottle' in axenic conditions as described by Nicot et al. (44).

Plant material. The population Ved124 used in our study consisted of 120 RILs $\left(F_{6}, F_{7}\right.$, and $\left.F_{8}\right)$ derived by single seed descent from a cross between cv. Védrantais, a Charentais type (Vilmorin,
France), and resistant genotype 'PI 124112', an Indian line. 'Védrantais' is susceptible to downy mildew and to all races of powdery mildew except race 0 of Podosphaera xanthii and G. cichoracearum.

Several accessions were used as controls in the tests. 'MR-1' is a breeding line derived from the Indian accession 'PI 124111' and resistant to Pseudoperonospora cubensis, Podosphaera xanthii, and G. cichoracearum (57). 'PI 414723' is also an Indian accession which is partially resistant to Pseudoperonospora cubensis and resistant to Podosphaera xanthii and G. cichoracearum. The American cv. Edisto 47, which has 'PI 124112' in its ancestry, is partially resistant to Pseudoperonospora cubensis and resistant to Podosphaera xanthii races $0,1,2,3$, and 4 and G. cichoracearum race 0 . The Uzbekistan land-race 'Ouzbèque 2' is highly susceptible to Pseudoperonospora cubensis.

Downy mildew evaluations. The 120 RILs, the parental lines 'Védrantais' and 'PI 124112', and the control lines ('Edisto 47', 'Ouzbèque 2', 'PI 414723', and 'MR-1') were evaluated for resistance to Pseudoperonospora cubensis. 'Edisto 47' and 'PI 414723' were not evaluated in some of the experiments.

The different melon lines were evaluated in six experiments conducted at different locations (Table 1). Two field experiments were performed under natural infection (experiments $\mathrm{A}$ and $\mathrm{B}$ ). One experiment was done under plastic tunnel with artificial inoculation (C). One experiment was performed using a leaf disk assay (D) as described by Epinat and Pitrat (18). Other experiments were carried out in a glasshouse by artificial inoculations: one experiment on cotyledons (E) and another one on true leaves (F). The experiments D, E, and F were repeated twice (D1, D2, E1, E2, F1, and F2). For each experiment, each RIL was evaluated in a complete randomized block design.

The first symptoms appeared between 7 and 10 days for experiments D, E, and F and between 21 and 30 days for experiments $\mathrm{A}$, $\mathrm{B}$, and C. As soon as symptoms appeared on a single plant of RIL or control, severity of symptoms was assessed on infected leaves or disks using semiquantitative rating scales, according to the experiments (Table 1).

Statistical analyses of downy mildew evaluations. Two variables were analyzed: the disease score at the final scoring date (TF) and the area under the disease progress curve (AUDPC). When several scorings per experiment were done (experiments A, $\mathrm{C}$, and D), the AUDPC was calculated for each RIL using the following formula: AUDPC $=\Sigma_{i}\left[\left(x_{i}+x_{i+1}-2\right) / 2\right]\left(t_{i+1}-t_{i}\right)$, with $i=1$ to 3 scorings, $x_{i}=$ mean disease score of each plant at date $i, x_{i+1}=$ mean disease score of each plant at date $i+1$, and $t_{i+1}-t_{i}=$ number of days between scoring date $i$ and scoring date $i+1$.

Data were analyzed for each experiment. Adjusted means of disease scores (least-squares [1s] means) of RILs on blocks and adjusted values of AUDPC of RILs were estimated by analysis of variance (ANOVA). Phenotypic correlations among the blocks, the experiments, and the variables were calculated. When repli-

TABLE 1. Conditions of the phenotypic evaluations of resistance to Pseudoperonospora cubensis in the 120 recombinant inbred lines derived from the cross between 'Védrantais' and 'PI 124112'a

\begin{tabular}{|c|c|c|c|c|c|c|c|c|}
\hline Experiment & Location & Condition & $\begin{array}{c}\text { Type of } \\
\text { inoculation }\end{array}$ & Organ evaluated & $\begin{array}{l}\text { Number } \\
\text { of block }\end{array}$ & $\begin{array}{c}\text { Number } \\
\text { of plants } \\
\text { per block }\end{array}$ & $\begin{array}{l}\text { Scoring } \\
\text { scale }\end{array}$ & $\begin{array}{l}\text { Number } \\
\text { of scoring }\end{array}$ \\
\hline A & RA & Open field & Natural & Leaves of adult plant & 2 & 1 & $1-3$ & 3 \\
\hline $\mathrm{C}$ & PACA & Plastic tunnel & Artificial & Leaves of plant with $10-15$ leaves & 3 & 3 & $1-3$ & 3 \\
\hline D1 & PACA & Growth chamber & Artificial & Leaf disks of plant with 2 leaves & 3 & 2 & $1-5$ & 3 \\
\hline D2 & PACA & Growth chamber & Artificial & Leaf disks of plant with 2 leaves & 2 & 1 & $1-5$ & 3 \\
\hline E1 & LR & Glasshouse & Artificial & Cotyledons of plant with one first leaf & 4 & 5 & $1-9$ & 1 \\
\hline $\mathrm{F} 2$ & LR & Glasshouse & Artificial & First leaf of plant & 4 & 7 & $1-9$ & 1 \\
\hline
\end{tabular}

a The evaluations were conducted in three regions of the South-East of France, Rhônes-Alpes (RA), Languedoc-Roussillon (LR), and Provence-Alpes-Côte d'Azur (PACA), under different conditions. 
cates were available for an experiment, broad-sense heritabilities $\left(h^{2}\right)$ were estimated from the mean square (MS) of ANOVA using the formula adapted from Gallais (22): $h^{2}=\sigma_{g}{ }^{2} /\left[\sigma_{g}{ }^{2}+\left(\sigma_{g r}{ }^{2} / r\right)+\right.$ $\left.\left(\sigma_{e}{ }^{2} / r n\right)\right]$ or $h^{2}=\sigma_{g}{ }^{2} /\left[\sigma_{g}{ }^{2}+\left(\sigma_{e}{ }^{2} / r\right)\right]$, where $\sigma_{g}{ }^{2}$ is the genetic variance (MSg - MSgr) $/ r n, \sigma_{g r}{ }^{2}$ is the genotype-test or the genotype-block interaction (MSgr-MSe) $/ n, \sigma_{e}{ }^{2}$ is the environmental variance (MSe), $n$ is the number of plants, and $r$ is the number of replicates.

Data analyses were performed with Statistical Analysis System (SAS) software (SAS Institute, Cary, NC). Variance analysis of disease scores and AUDPC was performed using PROC GLM of SAS with randomized effects.

Powdery mildew evaluations. The different strains of five races of Podosphaera xanthii and G. cichoracearum were tested in a leaf disk assay slightly modified from Epinat et al. (20). Leaf disks were placed in plastic boxes previously filled with $80 \mathrm{ml}$ of agar medium (mannitol, $10 \mathrm{~g}$ per liter; agar, $4 \mathrm{~g}$ per liter; and benzimidazole, $30 \mathrm{mg}$ per liter). Two types of leaf disks were inoculated, disks from young leaves and disks from older leaves. Since 1996, three experiments have been realized on 60 RILs with several strains of four races (Podosphaera xanthii races 1, 2, and 5 and $G$. cichoracearum race 1$)$. The second half of the population (60 RILs) was available in 2000 and has been evaluated for resistance to the same four races of Podosphaera xanthii and G. cichoracearum in two experiments. In 2002, race 3 of Podosphaera xanthii was tested on the 120 RILs in two experiments. Symptoms were rated individually for each leaf disk at 10 days after inoculation using a semiquantitative scoring scale from 1 to $9(1=$ no sporulations, $9=$ entire disk colonized with spores) corresponding to the surface and density of fungal colonization. Data were transformed on percentage of leaf disk surface (disease area or DA) using the class mean as suggested by Nicot et al. (44): $0=0 \%, 1=2.5 \%, 2=7.5 \%, 3=17.5 \%, 4=37.5 \%$, $5=67.5 \%, 6=82.5 \%, 7=92.5 \%, 8=97.5 \%$, and $9=100 \%$.

Phenotypic correlations among the experiments and the races were calculated. For the inheritance study, RILs with a DA $<10 \%$ were considered resistant and RILs with a DA $>10 \%$ were considered susceptible.

Genetic map construction. Genomic DNA of the RILs and parental lines was extracted from leaf tissue as described by Baudracco-Arnas (6). This set of lines was screened with 28 amplified fragment length polymorphism (AFLP) primer combinations, 45 simple sequence repeats (SSR) primers, 12 intermicrosatellite (IMA) primers, and two phenotypic markers ( $a$, andromonoecious; Prv, Papaya ringspot virus resistance). Twenty three AFLP primer combinations, 44 SSR primers $(16,17$,

\section{Experiment A}

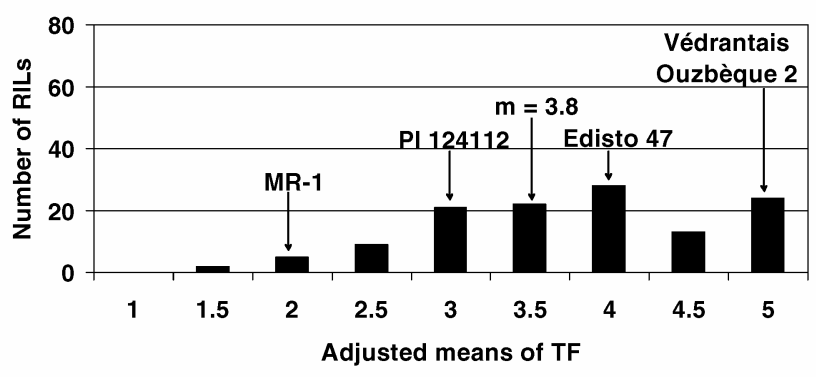

Experiment C

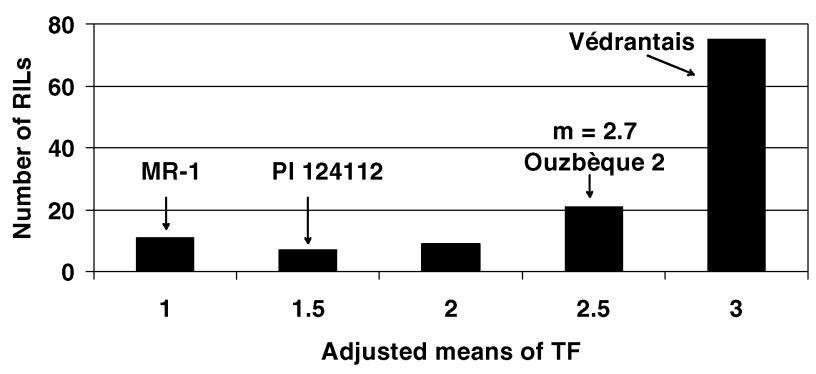

Experiment E1

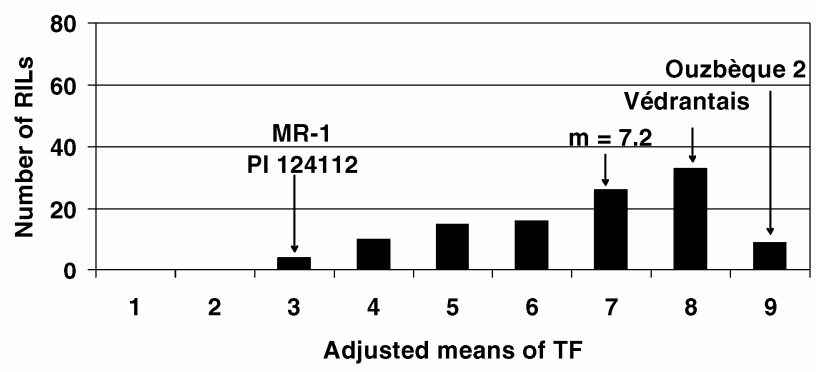

Experiment B

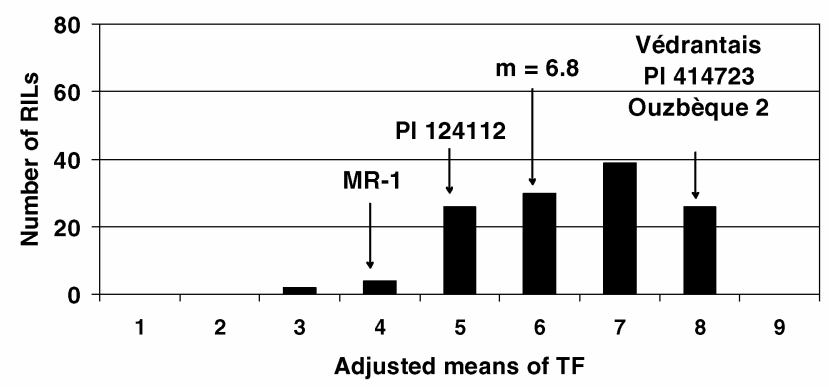

Experiment D1

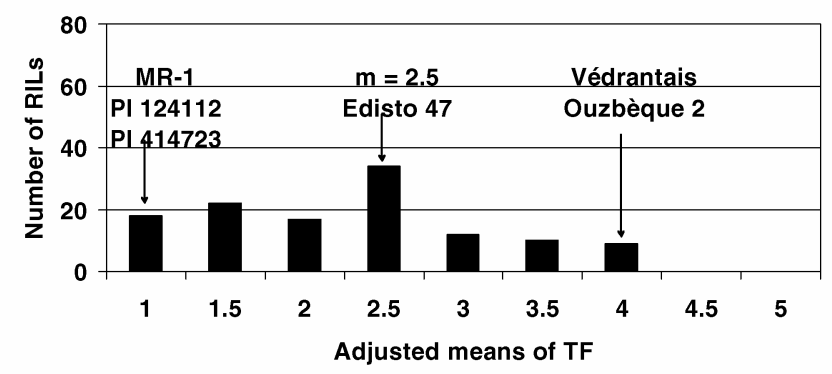

Experiment F1

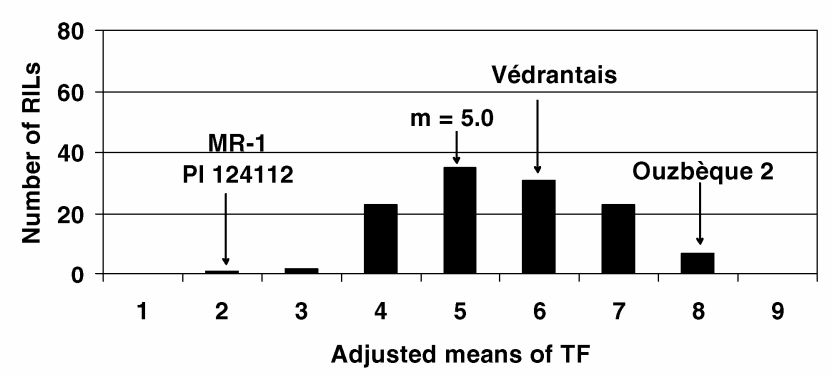

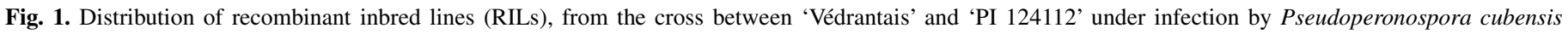

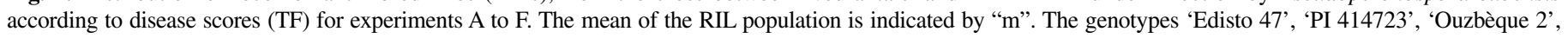
and 'MR-1' are the controls. 
29), and 12 IMA primer combinations (AA, AB, AE, B, E, F, J, L, $\mathrm{N}, \mathrm{R}, \mathrm{V}$, and $\mathrm{Y}$ ) were the same as those used to build the reference linkage map (45) and were used to assign the linkage groups (LGs). Five other AFLP primer combinations were used to try to saturate the genetic map (the EcoRI primer E32 = 5'-GACTGCGTACCAATTCAAC with MseI primers M47 to M51 = 5'GATGAGTCCTGAGTAACAA, $\underline{\mathrm{CAC}}, \underline{\mathrm{CAG}}, \underline{\mathrm{CAT}}$, and $\underline{\mathrm{CCA}}$, respectively). A new SSR was also used, Aco3-ms1 (1). The AFLP, SSR, and IMA analysis protocols were the same as described in Périn et al. (45).

The AFLP fragment was named by the primer combination followed by a number indicating the relative position of the band. The AFLP markers were numbered from 100. The IMA markers were named with a letter code followed by the approximate weight of the band. All the markers were scored by two people independently. Segregation of the markers among the RIL progeny was analyzed by the $\chi^{2}$ test. Markers with a strongly distorted segregation from the expected $1: 1(P<0.01)$ were eliminated. Since our RIL population had 'Védrantais' as a common parent with the reference map, the co-migrating DNA fragments in AFLP- and SSR-specific loci were used to assign the LGs.

The genetic map was constructed with the Mapmaker software version 3.0 (Whitehead Institute, Cambridge, UK). A logarithm of odds ratio (LOD) threshold of 5 was used to define LGs. Ordering markers was done using the "order" command. Markers that could not be confidently ordered were placed using the "try" command. Candidate orders were confirmed with the "ripple" command. The Kosambi function was used to calculate genetic distances (centimorgan [cM]) (34). When several markers clustered at the same position, the marker with the best segregation was conserved in order to construct a framework linkage map.

QTL detection. For downy mildew, the QTL detection was analyzed with 28 traits corresponding to the lsmeans of the disease scores (TF) and AUDPC (two variables for experiments A, $\mathrm{C}$, and $\mathrm{D}$; only TF for experiments $\mathrm{B}, \mathrm{E}$, and F), the means of the disease scores of each block (when the block effect was highly significant, $P<0.01$ ). The resistance to powdery mildew was analyzed for each experiment and each strain, previously reported in powdery mildew evaluations, of the five races (55 traits).

Variance analysis (LR), interval mapping (IM), and composite interval mapping (CIM) were performed with the QTL Cartographer software version 1.17 (C. J. Basten, B. S. Weir, and Z.-B. Zeng, North Carolina State University) for each trait. After performing 1,000 permutations with ANOVA, a LOD threshold of 3.1 for Pseudoperonospora cubensis and 3.3 for Podosphaera xanthii and G. cichoracearum was used to declare a putative QTL significant. For CIM, three to seven of the most informative markers per trait were chosen as cofactors. The same significance threshold was used for IM and CIM methods. For each significant QTL, a confidence interval corresponding to a LOD score drop of 1 on either side of the likelihood peaks was calculated. The QTL detected for several traits were interpreted to be the same QTL when the confidence interval of their position overlapped. For each trait, a multiway ANOVA was performed with molecular markers near the QTL peaks to estimate the total percentage of phenotypic variation $\left(R^{2}\right)$ explained by the significant QTL.

QTL were named by two letters indicating the pathogen, followed by the number of the LG it was associated with, and a number to distinguish several QTL on the same LG.

In addition to additive effects, digenic epistasis was tested with a two-factor ANOVA model with an interaction between pairs of markers. With the PROC GLM of SAS software, 37,675 interaction tests were performed and a significance level of $P<$ 0.00001 ( 0.4 false positive) was chosen for detecting digenic epistasis.

\section{RESULTS}

Phenotypic analyses of downy mildew and powdery mildew resistances. The variable TF was calculated for each Pseudoperonospora cubensis resistance experiment. The TF was used to demonstrate all the results of the phenotypic evaluations.

The parental lines 'Védrantais' and 'PI 124112' behaved, as expected, according to susceptibility and resistance. The controls, 'MR-1', 'Edisto 47', and 'Ouzbèque 2', also behaved as expected (resistant, intermediate, and susceptible, respectively). When the infection was severe, 'PI 414723' was not stable and shifted to susceptibility, such as in experiment B. Distributions of the RILs ranging in classes of disease scores (TF) showed a continuous variation (Fig. 1).

Data from the different experiments correlated significantly (Table 2). The correlation coefficients between the replications for experiments $\mathrm{D}\left(R^{2}=0.59\right), \mathrm{E}\left(R^{2}=0.7\right)$, and $\mathrm{F}\left(R^{2}=0.83\right)$ were highly significant. The correlation coefficients were highly significant between TF and AUDPC for experiments A $\left(R^{2}=0.86\right), \mathrm{C}$ $\left(R^{2}=0.98\right)$, and D $\left(R^{2}=0.97\right)$. The randomized blocks of the experiments were also significantly correlated, with $R^{2}$ ranging from 0.36 to 0.9 (data not shown).

Differences among RILs were highly significant (Table 3). At the $1 \%$ level, the block effect was significant for all the experiments, except A, B, and E1. The RIL-block interaction was significant for experiments C, D1, D2, E1, E2, F1, and F2.

Broad-sense heritabilities calculated from the different experiments ranged from 0.64 and 0.95 for TF (Table 4).

The parental lines 'Védrantais' and 'PI 124112' were susceptible and resistant to powdery mildew, respectively. Distributions of the RILs in classes of DA showed a different type of segregation (Fig. 2). Resistance to Podosphaera xanthii races 1 and 2 showed a $3: 1 \mathrm{resistant} /$ susceptible segregation type $\left(\chi^{2}=0, P=\right.$ $100 \% ; \chi^{2}=0.15, P=69.9 \%$, respectively) corresponding to two independent genes. Resistance to Podosphaera xanthii races 3 and 5 was controlled by one gene, with a $1: 1$ resistant/susceptible segregation $\left(\chi^{2}=0.008, P=92.7 \% ; \chi^{2}=2.94, P=8.7 \%\right.$, respectively). Resistance to $G$. cichoracearum race 1 also showed a significant segregation of $1: 1 \mathrm{resistant} /$ susceptible $\left(\chi^{2}=0.14, P=\right.$ $70.8 \%$ ).

The correlations between the different experiments, different strains of the races, and type of leaf disks (young or old leaves)

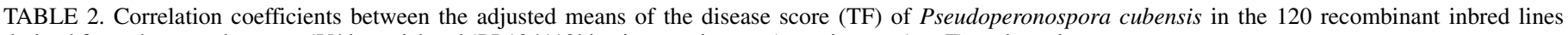
derived from the cross between 'Védrantais' and 'PI 124112' in six experiments (experiments A to F) evaluated ${ }^{\text {a }}$

\begin{tabular}{|c|c|c|c|c|c|c|c|c|}
\hline Experiments & A & B & $\mathrm{C}$ & D1 & D2 & E1 & E2 & F1 \\
\hline B & $0.51 * * *$ & $\ldots$ & $\ldots$ & $\ldots$ & $\ldots$ & $\ldots$ & $\ldots$ & $\ldots$ \\
\hline $\mathrm{C}$ & $0.39 * * *$ & $0.22 *$ & $\ldots$ & $\ldots$ & $\ldots$ & $\ldots$ & $\ldots$ & $\ldots$ \\
\hline D1 & $0.48 * * *$ & $0.44 * * *$ & $0.52 * * *$ & $\ldots$ & $\cdots$ & $\ldots$ & $\ldots$ & $\ldots$ \\
\hline D2 & $0.46^{* * * *}$ & $0.56 * * *$ & $0.40 * * *$ & $0.71 * * *$ & $\ldots$ & $\ldots$ & $\ldots$ & $\ldots$ \\
\hline E1 & $0.47 * * *$ & $0.37 * * *$ & $0.45 * * *$ & $0.56 * * *$ & $0.62 * * *$ & $\ldots$ & $\ldots$ & $\ldots$ \\
\hline E2 & $0.47 * * *$ & $0.42 * * *$ & $0.29 * *$ & $0.58 * * *$ & $0.58 * * *$ & $0.64 * * *$ & $\ldots$ & $\ldots$ \\
\hline $\mathrm{F} 1$ & $0.56^{* * * *}$ & $0.55 * * *$ & $0.57 * * *$ & $0.65 * * *$ & $0.70 * * *$ & $0.72 * * *$ & $0.54 * * *$ & $\ldots$ \\
\hline $\mathrm{F} 2$ & $0.61 * * *$ & $0.58 * * *$ & $0.53 * * *$ & $0.66 * * *$ & $0.65 * * *$ & $0.64 * * *$ & $0.60 * * *$ & $0.83 * * *$ \\
\hline
\end{tabular}

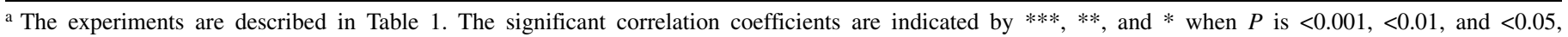
respectively. 
were significant (data not shown). Resistances to races 1 and 2 of Podosphaera xanthii were significantly correlated $\left(R^{2}=0.93\right)$ (Fig. 2). Race 2 resistance was significantly correlated to resistance to race $5\left(R^{2}=0.55\right)$ and race 3 of Podosphaera xanthii $\left(R^{2}=0.7\right)$ and race 1 of $G$. cichoracearum $\left(R^{2}=0.54\right)$. But race 3 resistance was not significantly correlated to resistance to race 5 of Podosphaera xanthii $\left(R^{2}=0.1\right)$ and race 1 of G. cichoracearum $\left(R^{2}=0.18\right)$. Correlation between resistance to race 5 and resistance to race 1 of $G$. cichoracearum was highly significant $\left(R^{2}=\right.$ 0.72 ).

It can be concluded that one gene is involved in the genetic control of resistance to races 1, 2, and 3 of Podosphaera xanthii and another independent gene controls resistance to races 1,2 , and 5. This latter gene is also involved in resistance to race 1 of G. cichoracearum.

The RILs most resistant to Pseudoperonospora cubensis were resistant to Podosphaera xanthii race 5, whereas the reverse was not always true (Fig. 3). Two-sample test of Kolmogorov-Smirnov assessed that the distributions of the resistant and susceptible RILs to Podosphaera xanthii race 5 were significantly different $(P<0.0001)$. The linkage between resistances to Pseudoperonospora cubensis and Podosphaera xanthii race 5 was demonstrated.

Genetic mapping. Among the 45 SSR primers tested, 17 were polymorphic between 'Védrantais' and 'PI 124112'. A percentage of $29.8 \%$ of the AFLP bands was found to be polymorphic between the parental lines. This corresponded well with the rate of polymorphism found by Périn et al. (45) between 'Védrantais' and 'PI 161375' (28.9\%).

The genetic map was obtained after linkage analysis of 465 AFLP, 17 SSR, 26 IMA, and two phenotypic markers ( $a$ and Prv). Thirty six LGs were obtained and 51 markers were not linked with a LOD of 5 . Among 36 ordered groups, 13 were assigned to 12 LGs of the reference map of melon (45). Between one to nine markers were used to assign each LG. The 23 nonassigned LGs were built of two to five markers and were numbered from LG13 to LG35. This unsaturated map spanned $1,150 \mathrm{cM}$. While the mean marker interval was $4.2 \mathrm{cM}$, the largest interval between two markers was $26.5 \mathrm{cM}$.

TABLE 3. Analysis of variance of the disease score (TF) of Pseudoperonospora cubensis in 120 recombinant inbred lines (RILs) derived from the cross between 'Védrantais' and 'PI 124112'

\begin{tabular}{llrccr}
\hline \multirow{2}{*}{ Experiment } & Effect & df & $\begin{array}{c}\text { Mean } \\
\text { square }\end{array}$ & $F$ value & $P$ value \\
\hline A & RIL & 118 & 1.57 & 4.99 & $<0.0001$ \\
& Block & 1 & 0.62 & 1.96 & 0.1640 \\
B & RIL & 115 & 4.16 & 3.45 & $<0.0001$ \\
& Block & 2 & 5.44 & 4.5 & 0.0121 \\
C & RIL & 118 & 2.48 & 5.78 & $<0.0001$ \\
& Block & 2 & 3.5 & 8.4 & 0.0003 \\
& RIL-block & 233 & 0.43 & 9.2 & $<0.0001$ \\
D1 & RIL & 116 & 8.5 & 4.85 & $<0.0001$ \\
& Block & 2 & 12.83 & 7.34 & 0.0008 \\
& RIL-block & 227 & 1.76 & 3.09 & $<0.0001$ \\
D2 & RIL & 117 & 21.8 & 2.97 & $<0.0001$ \\
& Block & 1 & 66.9 & 9.14 & 0.0031 \\
& RIL-block & 223 & 0.93 & 7.87 & $<0.0001$ \\
E1 & RIL & 116 & 29.43 & 9.02 & $<0.0001$ \\
& Block & 3 & 8.32 & 2.64 & 0.0495 \\
& RIL-block & 318 & 3.31 & 1.75 & $<0.0001$ \\
E2 & RIL & 115 & 56.88 & 4.58 & $<0.0001$ \\
& Block & 3 & 855.06 & 72.84 & $<0.0001$ \\
& RIL-block & 341 & 12.6 & 6.39 & $<0.0001$ \\
F1 & RIL & 115 & 16.67 & 14.69 & $<0.0001$ \\
& Block & 3 & 4.18 & 3.94 & 0.0088 \\
& RIL-block & 318 & 1.16 & 2.75 & $<0.0001$ \\
F2 & RIL & 114 & 50.93 & 20.85 & $<0.0001$ \\
& Block & 3 & 78.59 & 33.87 & $<0.0001$ \\
& RIL-block & 341 & 2.46 & 3.39 & $<0.0001$ \\
\hline
\end{tabular}

QTL detection. QTL detection did not significantly differ between the three detection methods, LR, IM, or CIM. Because of the more accurate estimations of $R^{2}$ values and additive effects with CIM (64), we choose to present CIM results only.

One major Pseudoperonospora cubensis resistance QTL, pcXII.1, was detected for all 28 traits studied. This QTL explained from 12 to $38 \%$ of the phenotypic variance (Table 5). Other QTL were detected for several but not all traits (pcIV.1, pcVI.1, pcVIII.1, and $p c X I .2)$. For instance, the QTL pcIV.1 was detected for experiments A, B, and F1 and explained from 7.9 to $13 \%$ of the phenotypic variance. Six other QTL were detected: pcII.1 for experiment $\mathrm{B}, p c X I .1$ for experiment $\mathrm{A}$, or on one replicate of one experiment, $p c 16.1, p c 24.1, p c 32.1$ or for one variable (AUDPC) of one experiment (D1), pcVI.2. The QTL pcVIII.1 and pc24.1 had a negative additive effect, indicating that the 'Védrantais' allele improves the resistance to Pseudoperonospora cubensis. The results of QTL detection on each block of experiments C, D1, D2, E2, F1, and F2 were the same as those obtained with the adjusted means on blocks (data not shown).

All confidence intervals of the pcIV.1, pcVIII.1, and pcXII.1 QTL overlapped on a common segment of LGs (Fig. 4). On LGVI and LGXI, confidence intervals of each QTL detected did not overlap and were considered different QTL.

Thirteen significant digenic interactions were detected for six experiments, but none were the same between two experiments (data not shown).

The total $R^{2}$ accounted by all QTL with additive effects for resistance to Pseudoperonospora cubensis ranged from 14 to $50.3 \%$ for all the experiments.

For powdery mildew experiments, one major QTL, PmV.1, was detected and explained $89 \%$ of the phenotypic variation of resistance to Podosphaera xanthii race 3 and corresponded to a monogenic control. One major QTL corresponding to monogenic control for resistance to race 5 of Podosphaera xanthii was detected on LGXII, PmXII.1, which explained 93\% of the phenotypic variation (Table 6). Two major QTL were identified for resistance to races 1 and 2 of Podosphaera xanthii on LGV and LGXII, PmV.1 which explained 33 and $39 \%$ of the variation and PmXII.1 which explained 25 and $29 \%$ of the variation. The same QTL, PmXII.1, explained $32 \%$ of the resistance to G. cichoracearum race 1. This detection was assessed for all the traits (data not shown).

Three digenic epistatic interactions were found to have a significant effect on Podosphaera xanthii and G. cichoracearum. The interaction between PmV.1 and PmXII.1 accounted for 68 and $80 \%$ of the variation for the resistance to Podosphaera xanthii races 1 and $2\left(P=9.10^{-14}\right.$ and $1.10^{-19}$, respectively). The two other significant interactions were detected between PmXII.1 and an IMA marker AB_1600 (LGIV) and between the AFLP marker H36/M37-114_1 (LGIII) and AB_1600. They explained 22 and $20 \%$ of the variation of the resistance to $G$. cichoracearum race 1 $\left(P=2.10^{-5}\right.$ and $6.10^{-6}$, respectively).

\section{DISCUSSION}

In this paper, we report the construction of an unsaturated linkage map based on a RIL population derived from the cross between 'Védrantais' and 'PI 124112', which allowed us to assess

TABLE 4. Genetic analysis of the resistance to Pseudoperonospora cubensis in the recombinant inbred line progeny from the cross between 'Védrantais' and 'PI 124112' a

\begin{tabular}{|c|c|c|c|c|c|c|c|c|c|}
\hline Parameter & A & B & $\mathrm{C}$ & D1 & D2 & E1 & $\mathrm{E} 2$ & $\mathrm{~F} 1$ & $\mathrm{~F} 2$ \\
\hline$h^{2}$ & 0.80 & 0.71 & 0.88 & 0.79 & 0.64 & 0.89 & 0.78 & 0.93 & 0.95 \\
\hline
\end{tabular}


the polygenic inheritance of resistance to Pseudoperonospora cubensis and to localize resistance genes to powdery mildew.

The melon genome is predicted to have 12 LGs. The common parental line 'Védrantais' and the use of a few common markers allowed the assignment of the 12 LGs of the Ved124 map onto the reference map built with two other RIL populations ('Védrantais' $x$ 'PI 161375' and 'Védrantais' $\times$ 'PI 414723') (45). The SSR

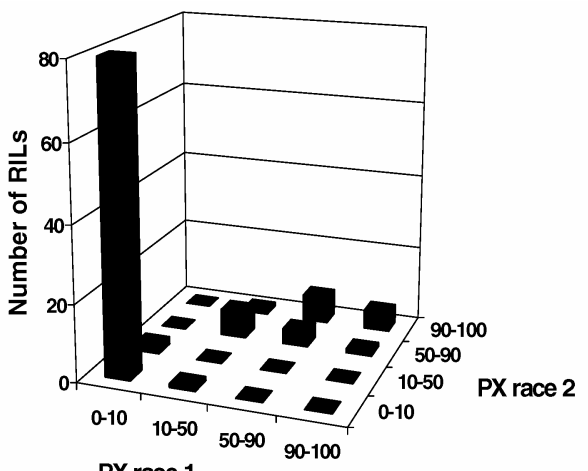

PX race 1

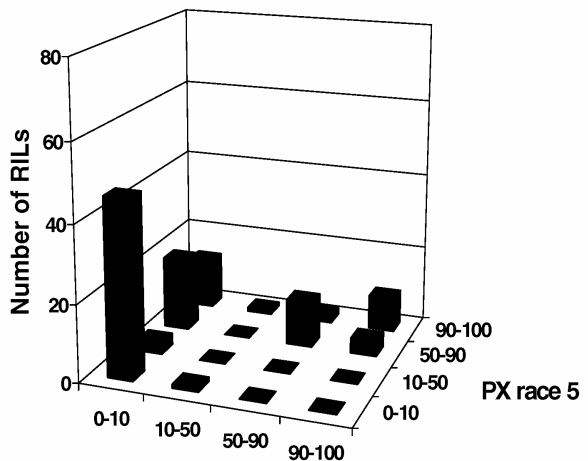

PX race 2

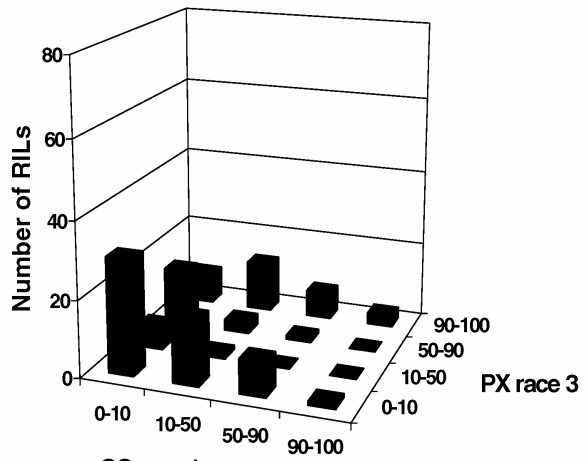

GC race 1

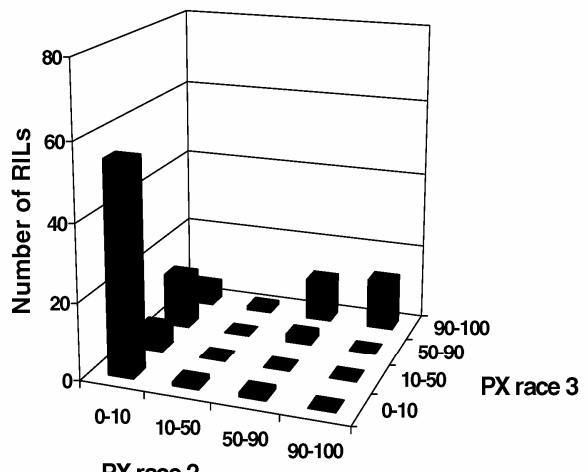

PX race 2 provide co-dominant, locus-specific markers that are effective anchor points for map merging. AFLPs are dominant fingerprinting markers that are quite well distributed on our Ved124 map but also transportable between crosses. Thirty five LGs were defined, including the 12 LGs previously published, and the genome coverage $(1,150 \mathrm{cM})$ was below the $1,654 \mathrm{cM}$ of the published reference map.

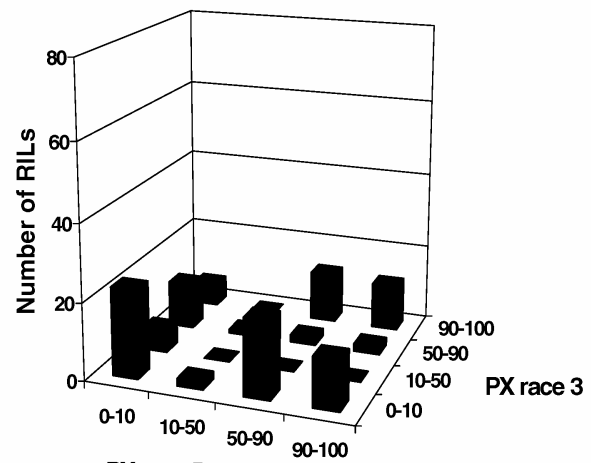

PX race 5

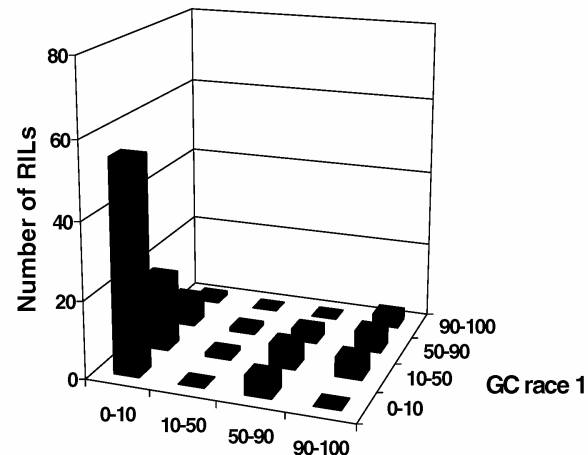

PX race 2

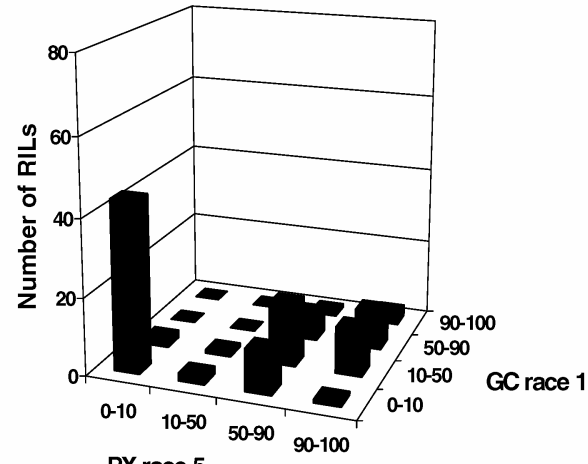

PX race 5

Fig. 2. Distribution of recombinant inbred lines (RILs), from the cross between 'Védrantais' and 'PI 124112' under infection by different races of Podosphaera xanthii (PX) and Golovinomyces cichoracearum (GC) race 1 according to disease area. 
In spite of the fact that our map was unsaturated, 11 QTL were identified for resistance to Pseudoperonospora cubensis on six LGs and three unassigned groups (Fig. 4). The confidence interval of the QTL did not always overlap. This may be due to the following: (i) the number of RILs was too low, (ii) the map was unsaturated, or (iii) resistance experiments were carried out under multiple conditions. The QTL detected on LGVI ( $p c V I .1$ and $p c V I .2)$ and on LGXI ( $p c X I .1$ and $p c X I .2)$ may be considered as

\section{$\square$ Susceptible to $\mathrm{PX}$ race 5 Q Resistant to $\mathrm{PX}$ race 5}

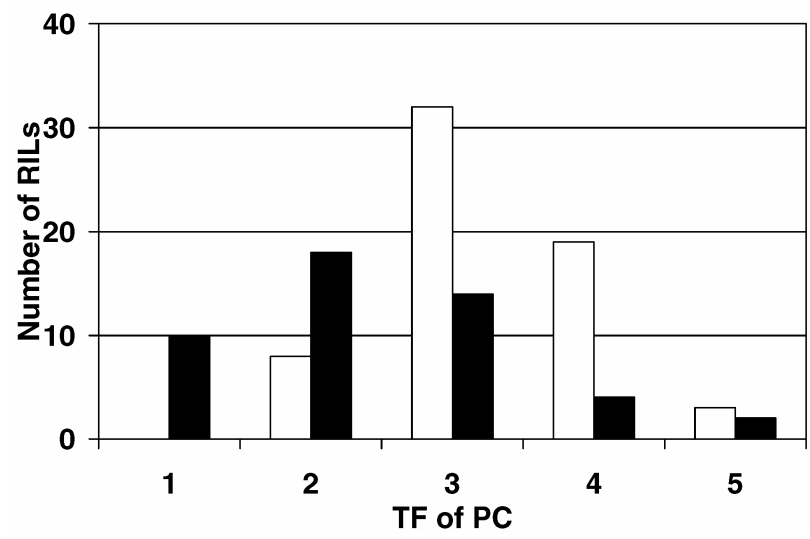

Fig. 3. Distribution of recombinant inbred lines (RILs) resistant or susceptible to Podosphaera xanthii (PX) race 5 according to the disease scores (TF) of Pseudoperonospora cubensis (PC). the same QTL. Thus, nine QTL were involved in control of resistance to Pseudoperonospora cubensis.

The resistance alleles of seven QTL originated from the partially resistant parent 'PI 124112'. Resistance alleles of two QTL, pcVIII.1 and pc24.1, were identified as originating from the susceptible line 'Védrantais'. Alleles from the susceptible parent that enhance disease resistance were already reported for several hostpathogen interactions $(2,3,21)$.

Among the nine QTL detected, one QTL with major effect was consistent over all the traits, all the experiments, and all planting conditions. This QTL, $p c X I I .1$, explained a high proportion of the phenotypic variation, between 12 and $38 \%$. Finding one or two major QTL stable across environments has been observed for various pathosystems $(23,30,46,52)$. pcXII.1 was probably responsible for the phenotypic correlations between the experiments, replications, and blocks. This QTL may be constitutive or expressed all along the host-pathogen interaction and may correspond to resistance genes (37). Resistance to Pseudoperonospora cubensis has been evaluated with only one strain using the artificial inoculations. An unknown number of strains were in field experiments in which the inoculum was not controlled. So pcXII.1 may be a nonspecific resistance factor. Four QTL were consistent over two or three experiments and four QTL were replication or location specific. Incomplete correlation between experiments may result from plant age, different populations of Pseudoperonospora cubensis, different environmental conditions, or pathogen development and disease pressure. The expression of the individual QTL may display specificities, such as QTL $p c 16.1$ and $p c 24.1$, which appear to be specific for the leaf disks, and $p c 32.1$, which appears to be specific for the cotyledons.

TABLE 5. The quantitative trait loci (QTL) associated with the resistance to Pseudoperonospora cubensis in 120 recombinant inbred lines derived from the cross between 'Védrantais' and 'PI 124112' for six experiments, two variables (disease scores and area under disease progress curve [AUDPC]), and two replications of each experiment when data were available ${ }^{\mathrm{a}}$

\begin{tabular}{|c|c|c|c|c|c|c|c|}
\hline Experiment & Variable & QTL & Position (cM) & LOD & $R^{2}(\%)$ & Additive effect & $\begin{array}{c}\text { Total } R^{2} \text { explained } \\
\text { by all QTL }(\%)\end{array}$ \\
\hline A & $\begin{array}{l}\text { TF } \\
\text { AUDPC }\end{array}$ & $\begin{array}{l}p c X I .1 \\
\text { pcXII.1 } \\
\text { pcIV.1 } \\
\text { pcVI.1 } \\
\text { pcXI.1 } \\
\text { pcXII.1 }\end{array}$ & $\begin{array}{l}16.8 \\
24.2 \\
24.8 \\
48.3 \\
16.8 \\
24.0\end{array}$ & $\begin{array}{r}3.00 \\
13.68 \\
4.07 \\
3.97 \\
3.64 \\
13.3\end{array}$ & $\begin{array}{r}5.3 \\
31.1 \\
7.9 \\
8.2 \\
6.6 \\
29.3\end{array}$ & $\begin{array}{l}0.21 \\
0.52 \\
3.96 \\
4.08 \\
3.62 \\
7.82\end{array}$ & $\begin{array}{c}46.6 \\
\ldots \\
50.3 \\
\ldots \\
\ldots \\
\ldots\end{array}$ \\
\hline B & $\mathrm{TF}$ & $\begin{array}{l}\text { pcII.1 } \\
\text { pcIV.1 } \\
\text { pcVIII.1 } \\
\text { pcXII.1 }\end{array}$ & $\begin{array}{r}73.8 \\
4.0 \\
152.8 \\
17.5\end{array}$ & $\begin{array}{l}4.24 \\
3.92 \\
3.04 \\
5.17\end{array}$ & $\begin{array}{l}11.6 \\
13.6 \\
11.3 \\
13.2\end{array}$ & $\begin{array}{r}0.41 \\
0.44 \\
-0.40 \\
0.44\end{array}$ & $\begin{array}{c}19.0 \\
\ldots \\
\ldots \\
\ldots\end{array}$ \\
\hline $\mathrm{C}$ & $\begin{array}{l}\text { TF } \\
\text { AUDPC }\end{array}$ & $\begin{array}{l}\text { pcXII.1 } \\
\text { pcXII.1 }\end{array}$ & $\begin{array}{l}20.0 \\
17.5\end{array}$ & $\begin{array}{l}5.42 \\
6.3\end{array}$ & $\begin{array}{l}20.1 \\
18.1\end{array}$ & $\begin{array}{l}0.26 \\
3.36\end{array}$ & $\begin{array}{l}14.0 \\
20.5\end{array}$ \\
\hline D1 & $\begin{array}{l}\text { TF } \\
\text { AUDPC }\end{array}$ & $\begin{array}{l}\text { pcVI.1 } \\
\text { pcXII.1 } \\
\text { pcVI.2 } \\
\text { pcXII.1 }\end{array}$ & $\begin{array}{l}46.3 \\
22.0 \\
30.3 \\
15.0\end{array}$ & $\begin{array}{l}4.84 \\
6.95 \\
3.33 \\
7.2\end{array}$ & $\begin{array}{l}13.9 \\
25.4 \\
10.2 \\
20.3\end{array}$ & $\begin{array}{l}0.33 \\
0.44 \\
0.85 \\
1.2\end{array}$ & $\begin{array}{c}24.0 \\
\ldots \\
21.6 \\
\ldots\end{array}$ \\
\hline E1 & $\mathrm{TF}$ & $\begin{array}{l}\text { pcVI.1 } \\
\text { pcXII.1 }\end{array}$ & $\begin{array}{l}56.9 \\
24.2\end{array}$ & $\begin{array}{c}5.1 \\
14.45\end{array}$ & $\begin{array}{l}13.1 \\
37.8\end{array}$ & $\begin{array}{l}0.54 \\
0.93\end{array}$ & $\begin{array}{c}31.2 \\
\ldots\end{array}$ \\
\hline E2 & $\mathrm{TF}$ & $\begin{array}{l}p c X I .2 \\
p c X I I .1 \\
p c 32.1\end{array}$ & $\begin{array}{r}28.1 \\
26.2 \\
2.0\end{array}$ & $\begin{array}{r}3.00 \\
13.66 \\
3.25\end{array}$ & $\begin{array}{r}5.6 \\
35.5 \\
7.8\end{array}$ & $\begin{array}{l}0.40 \\
1.01 \\
0.47\end{array}$ & $\begin{array}{c}44.7 \\
\ldots \\
\ldots\end{array}$ \\
\hline F1 & $\mathrm{TF}$ & $\begin{array}{l}\text { pcIV.1 } \\
\text { pcVIII.1 } \\
\text { pcXII.1 }\end{array}$ & $\begin{array}{r}16.1 \\
152.8 \\
24.2\end{array}$ & $\begin{array}{l}3.05 \\
5.13 \\
5.02\end{array}$ & $\begin{array}{r}8.0 \\
20.5 \\
12.1\end{array}$ & $\begin{array}{r}0.34 \\
-0.53 \\
0.42\end{array}$ & $\begin{array}{c}24.6 \\
\ldots \\
\ldots\end{array}$ \\
\hline $\mathrm{F} 2$ & $\mathrm{TF}$ & $\begin{array}{l}\text { pcVIII.1 } \\
\text { pcXI.2 } \\
\text { pcXII.1 }\end{array}$ & $\begin{array}{r}156.2 \\
30.9 \\
24.0\end{array}$ & $\begin{array}{r}5.56 \\
2.93 \\
10.55\end{array}$ & $\begin{array}{r}15.0 \\
6.0 \\
25.0\end{array}$ & $\begin{array}{r}-0.63 \\
0.41 \\
0.84\end{array}$ & $\begin{array}{c}40.8 \\
\ldots \\
\ldots\end{array}$ \\
\hline
\end{tabular}

\footnotetext{
a Name of QTL, the position of the peak of LOD scores, the significant peak values of LOD scores, the percentage of phenotypic variance explained, the additive
} effects, and the total phenotypic variance explained by QTL based on composite interval mapping analysis are summarized. 
These QTL may be specifically expressed or induced in particular organs (37).

The artificial inoculation test performed in growth chambers and on leaf disks (experiment D) was significantly correlated to the experiments under natural infection, but did not explain all the Pseudoperonospora cubensis resistance detected. This demonstrates the need to evaluate Pseudoperonospora cubensis resistance in several locations and conditions over several years to state the individual effect of QTL accurately.

The broad-sense heritabilities ranged from 0.64 to 0.95 indicating a good estimation of the genotypic value by the phenotypic evaluations. The heritabilities of experiments B and D2 were lower than the others because of environmental conditions such as temperature and moisture affecting the epidemics in the field (B), and the less severe infection on leaf disks (D2). The total phenotypic variance explained by all detected QTL ranged from 14 to $50 \%$. Comparison with the values of broad-sense heritabilities suggested that all the genetic variance was not explained by these QTL. This may result from the existence of resistance loci in genomic regions not covered by our genetic map or from the choice of the significance threshold which could have prevented the detection of minor QTL. The involvement of epistatic interactions in the unexplained part of the variation is hypothesized and shown by 13 significant interactions. None of these digenic interactions was consistently identified. Liao et al. (38) detected different epistatic effects under two experimental conditions and thus suggested that the effects of environment are greater on epistatic loci than on QTL.

Powdery mildew resistance was more simply inherited. Resistance to Podosphaera xanthii race 3 was controlled by one major gene localized on LGV, PmV.1. One major gene, PmXII.1 localized on LGXII, was involved in the resistance to Podosphaera xanthii race 5. Resistance to Podosphaera xanthii races 1 and 2 was controlled by either PmV.1 or PmXII.1. Resistance to

TABLE 6. The quantitative trait loci (QTL) associated with the resistance to powdery mildew (Podosphaera xanthii and Golovinomyces cichoracearum) in 120 recombinant inbred lines derived from the cross between 'Védrantais' and 'PI 124112' for the disease area ${ }^{\mathrm{a}}$

\begin{tabular}{llclc}
\hline Races & QTL & Position $(\mathrm{cM})$ & LOD & $R^{2}(\%)$ \\
\hline Podosphaera xanthii race 1 & PmV.1 & 72.9 & 12.16 & 32.9 \\
& PmXII.1 & 9.2 & 10.1 & 24.8 \\
Podosphaera xanthii race 2 & PmV.1 & 72.9 & 16.19 & 38.9 \\
& PmXII.1 & 9.2 & 13.0 & 28.8 \\
Podosphaera xanthii race 3 & PmV.1 & 72.9 & 48.31 & 88.9 \\
Podosphaera xanthii race 5 & PmXII.1 & 9.1 & 55.1 & 93.1 \\
G. cichoracearum race 1 & PmXII.1 & 9.2 & 11.74 & 32.1 \\
\hline
\end{tabular}

a Name of QTL, the position of the peak of LOD scores, significant peak values of LOD scores, and the percentage of phenotypic variance explained by QTL based on composite interval mapping analysis are summarized.

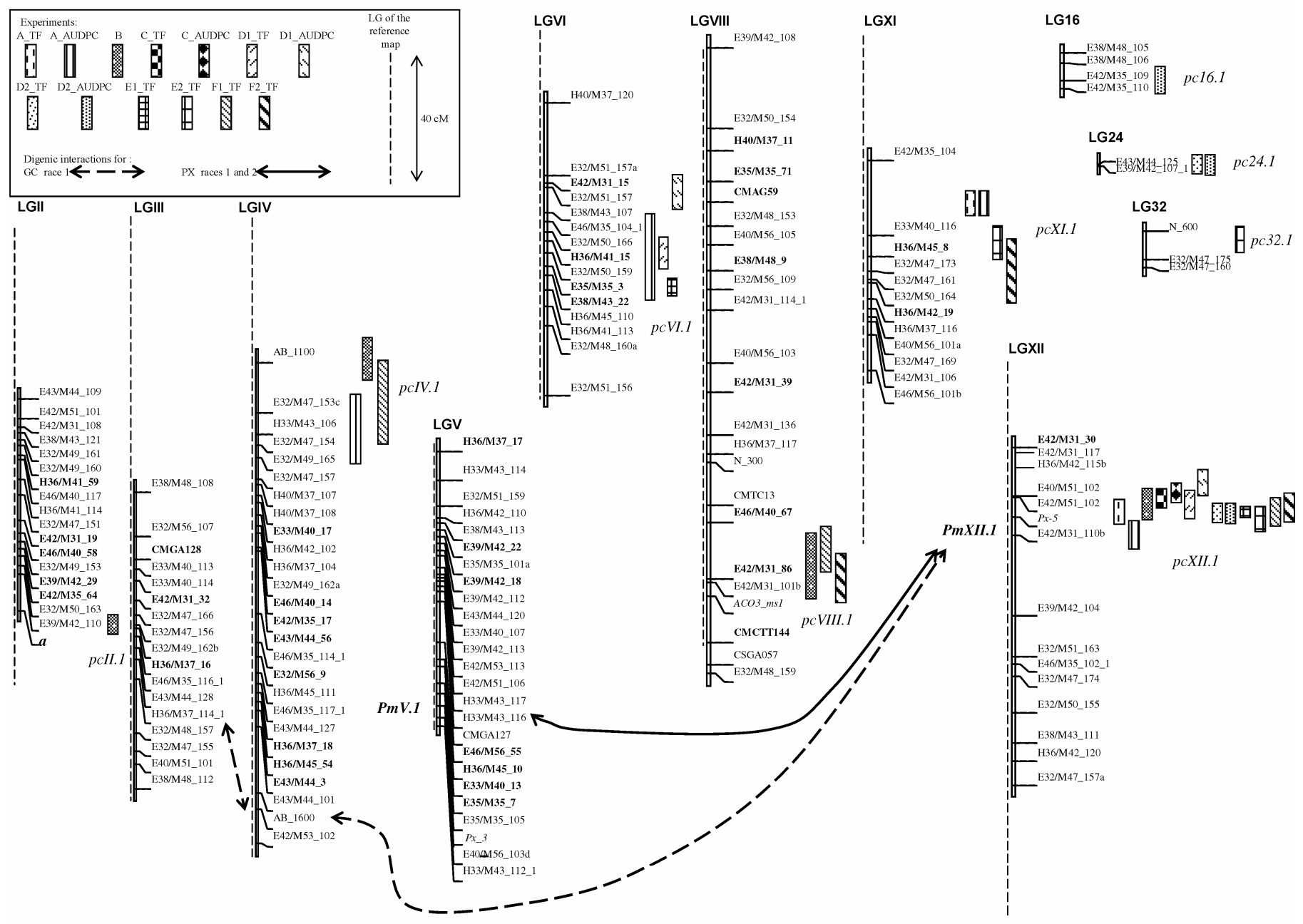

Fig. 4. Linkage groups (LGs), downy mildew $(p c)$ and powdery mildew $(P m)$ resistance quantitative trait loci (QTL) detected on the RILs progeny derived from the cross between 'Védrantais' and 'PI 124112'. Only the LGs on which some QTL and digenic interactions have been detected are represented. The QTL length represents the confidence interval: the distance equivalent to an LOD decrease of 1 on each side of the position of the maximal LOD value. The co-migrating loci of amplified fragment length polymorphism and simple sequence repeats specific loci between the Ved124 linkage map and the reference map (45) are indicated in bold type and numbered as in the reference map. 
G. cichoracearum race 1 was more complex to define, because only one QTL was detected, PmXII.1, which explained only $32 \%$ of the phenotypic variation. Moreover, one digenic interaction occurred between PmXII.1 and one marker located on LGIV, and another digenic epistatic interaction was detected between "background" loci on LGIII and LGIV. These results were not consistent with those of other studies. Indeed, inheritance of resistance to Podosphaera xanthii races 1 and 2 has already been studied by Kenigsbuch and Cohen (33), who showed that resistance to races 1 and 2 of Podosphaera xanthii was controlled by two different genes (Pm4 for race 2 and $P m 5$ for race 1). Their race 2 strain was possibly different than the race 2 'Europe', Sm1, used in our study. Indeed, using differential lines other than 'PMR 45', McCreight et al. (40) demonstrated that race 2 'Europe' and race 2 'US' were different. One dominant gene $\left(\mathrm{Pm}-\mathrm{C}^{2}\right)$, controlling the resistance to both races (race 1 and race 2 'Europe'), was described by Epinat et al. (20) in $\mathrm{F}_{1}, \mathrm{~F}_{2}$, and $\mathrm{BC}$ progenies of the cross between 'Védrantais' and 'PI 124112'. One of the two resistance genes, PmV.1 or PmXII.1, may not be completely dominant and consequently not detected from the genetic study of Epinat et al. (20). The fact that two independent genes controlled resistance to Podosphaera xanthii races 1, 2, 3, and 5 and $G$. cichoracearum race 1 was also inconsistent with the study of Bardin et al. (5) on Podosphaera xanthii races 1, 2, 4, and 5, who hypothesized that four genes were linked in a cluster. Many assumptions underlied this hypothesis. Moreover, molecular markers and QTL detection allowed us to identify and localize the genetic factors involved in resistance. Thus, we can confirm the simple inheritance of resistance to Podosphaera xanthii races 1, 2, 3 , and 5 .

On LGV, the PmV.1 locus for resistance to Podosphaera xanthii races 1,2 , and 3 co-localized with the resistance genes Vat, which confers resistance to aphid colonization and virus transmission, and $P m-w$ for resistance to Podosphaera xanthii races 1,2 , and 3 in 'WMR-29' (45). Therefore, a cluster of resistance genes may be present in this genomic region. The existence of simply inherited genes, or clusters of separate tightly linked genes, that confer resistance to several pathogens has been described in other cucurbits, such as cucumber with potyviruses (25) and in several other plant species $(15,50)$. About $60 \%$ of the resistance genes are clustered. The resistance genes present in a given cluster can confer resistance to different strains of the same pathogen or to different pathogens (63).

Recently, two photorespiratory peroxisomal enzymes, proteins glyoxylate aminotransferases Atl and At2, belonging to a different class of $\mathrm{R}$ genes, were cloned and shown to display resistance against Pseudoperonospora cubensis in the melon line 'PI $124111 \mathrm{~F}$ ' (55). One of these genes may be one of the two complementary genes identified to control resistance in 'PI 124112' by Kenigsbuch and Cohen $(31,32)$. To assess the molecular nature of genetic factors involved in resistance to Pseudoperonospora cubensis in 'PI 124112', polymorphism of these enzymatic genes will need to be tested and these genes will need to be mapped to determine if they co-localize with one of the resistance QTL to Pseudoperonospora cubensis.

On LGXII, the major resistance QTL for Pseudoperonospora cubensis, pcXII.1, was detected on PmXII.1, resistance gene to Podosphaera xanthii races 1,2 , and 5 and G. cichoracearum race 1. So one of the major genetic factors involved in resistance to Pseudoperonospora cubensis is linked with the locus, PmXII.1, involved in the powdery mildew resistance. This result is illustrated in Figure 3. Other studies showed that the gene Run 1 from Muscadinia, responsible for total resistance to the powdery mildew species Uncinula necator, is linked with the resistance to downy mildew caused by Plasmopara viticola $(35,41)$. The loci implicated in these resistances may be different but tightly linked. The presence of both quantitative and qualitative resistance genes in the same genomic regions suggests that the QTL may corre- spond to allelic variation of qualitative resistance genes with intermediate phenotypes (51). It has been demonstrated that genes sharing a common structure with $\mathrm{R}$ genes could trigger a weak resistance.

A stable resistance may be obtained by a combination of complete and partial resistance factors. Pyramiding qualitative resistance genes with different race specificities has been proposed as a way to increase the likelihood of the predicted resistance durability to stem rust on spring wheat (53). In 'PI 124112', the powdery mildew resistance genes located on LGXII and LGV are already pyramided. In the case of quantitative resistance to Pseudoperonospora cubensis, the major QTL pcXII.1 is stable over locations and infection conditions and seems to be a nonspecific genetic factor. Moreover, resistance of this QTL is linked with powdery mildew resistance to Podosphaera xanthii races 1 , 2 , and 5 and $G$. cichoracearum race 1 . The combination of both types of resistance genes (qualitative and quantitative) offers the possibility of exploiting both the complete effect of the qualitative resistance genes with the theoretical durability of the quantitative resistance gene (11).

\section{ACKNOWLEDGMENTS}

L. Perchepied thanks Amélioration des Semences Legumières, ClauseTezier, Gautier, Rijk Zwaan, Seminis, and Takii seed companies for technical assistance and the seed companies and Association Nationale de la Recherche Technique (France) for financial support. We thank N. Giovinazzo, V. Chareyron, D. Besombes, and C. Troulet for technical assistance.

\section{LITERATURE CITED}

1. Akashi, Y., Shiomi, S., Kubo, Y., Masuda, M., and Kato, K. 2001. Microsatellite and CAPS markers for ethylene-related genes, 1-aminocyclopropane-1-carboxylic acid (ACC) synthase and ACC oxidase genes, and their variation in melon (Cucumis melo L.). Breed. Sci. 51:107-112.

2. Al-Chaarani, G. R., Roustaee, A., Gentzbittel, L., Mokrani, L., Barrault, G., Dechamp-Guillaume, G., and Sarrafi, A. 2002. A QTL analysis of sunflower partial resistance to downy mildew (Plasmopara halstedii) and black stem (Phoma macdonaldii) by the use of recombinant inbred lines (RILs). Theor. Appl. Genet. 104:490-496.

3. Arahana, V. S., Graef, G. L., Specht, J. E., Steadman, J. R., and Eskridge, K. M. 2001. Identification of QTLs for resistance to Sclerotinia sclerotiorum in soybean. Crop Sci. 41:180-188.

4. Bardin, M., Carlier, J., and Nicot, P. C. 1999. Genetic differentiation in the French population of Erysiphe cichoracearum, a causal agent of powdery mildew of cucurbits. Plant Pathol. 48:531-540.

5. Bardin, M., Dogimont, C., Nicot, P. C., and Pitrat, M. 1999. Genetic analysis of resistance of melon line PI 124112 to Sphaerotheca fuliginea and Erysiphe cichoracearum, studied in recombinant inbred lines. Acta Hortic. 492:163-168.

6. Baudracco-Arnas, S. 1995. A simple and inexpensive method for DNA extraction from Cucumis melo L. Cucurbit Genet. Coop. Rep. 18:50-51.

7. Bertrand, F., and Pitrat, M. 1989. Screening of a muskmelon germplasm for susceptibility to 5 pathotypes of powdery mildew. Pages 140-142 in: 'Cucurbitaceae 89'. C. E. Thomas, ed. Charleston, SC.

8. Blancard, D., Pitrat, M., and Jourdain, F. 1989. Etude de la sporulation de Pseudoperonospora cubensis (Berk. et Curt.) Rost. sur cotylédons de melon; Application à la recherche de variétés résistantes. Phytopathol. Mediterr. 28:169-175.

9. Braun, U., Cook, R. T. A., Inman, A. J., and Shin, H. D. 2002. The taxonomy of the powdery mildew fungi. Pages 13-55 in: The Powdery Mildews: A Comprehensive Treatise. R. R. Belanger, W. R. Bushnell, A. J. Dik, and T. L. W. Carver, eds. The American Phytopathological Society, St. Paul, MN.

10. Brown, J. K. M. 2002. Comparative genetics of avirulence and fungicide resistance in the powdery mildew fungi. Pages 56-65 in: The Powdery Mildews: A Comprehensive Treatise. R. R. Bélanger, W. R. Bushnell, A. J. Dik, and L. W. Carver, eds. The American Phytopathological Society, St. Paul, MN.

11. Castro, A. J., Capettini, F., Corey, A. E., Filichkin, T., Hayes, P. M., Kleinhofs, A., Kudrna, D., Richardson, K., Sandoval-Islas, S., Rossi, C., and Vivar, H. 2003. Mapping and pyramiding of qualitative and quantitative resistance to stripe rust in barley. Theor. Appl. Genet. 107:922-930. 
12. Cohen, Y., Cohen, S., Eyal, H., and Thomas, C. E. 1985. Inheritance of resistance to downy mildew in Cucumis melo PI 124111. Cucurbit Genet. Coop. Rep. 8:36-38.

13. Cohen, Y., and Eyal, H. 1988. Reaction of muskmelon genotypes to races 1 and 2 of Sphaerotheca fuliginea in Israel. Cucurbit Genet. Coop. Rep. 11:47-49.

14. Cohen, Y., Meron, I., Mor, N., and Zuriel, S. 2003. A new pathotype of Pseudoperonospora cubensis causing downy mildew in cucurbits Israel. Phytoparasitica 31:458-466.

15. Crute, I. R., and Pink, D. A. C. 1996. Genetics and utilization of pathogen resistance in plants. Plant Cell 8:1747-1755.

16. Danin-Poleg, Y., Reis, N., Baudracco-Arnas, S., Pitrat, M., Staub, J. E., Oliver, M., Arús, P., de Vicente, C. M., and Katzir, N. 2000. Simple sequence repeats in Cucumis mapping and map merging. Genome 43:963974.

17. Danin-Poleg, Y., Reis, N., Tzuri, G., and Katzir, N. 2001. Development and characterization of microsatellite markers in Cucumis. Theor. Appl. Genet. 102:61-72.

18. Epinat, C., and Pitrat, M. 1994. Inheritance of resistance to downy mildew (Pseudoperonospora cubensis) in muskmelon (Cucumis melo). I. Analysis of a $8 \times 8$ diallel table. Agronomie 14:239-248.

19. Epinat, C., and Pitrat, M. 1994. Inheritance of resistance to downy mildew (Pseudoperonospora cubensis) in muskmelon (Cucumis melo). II. Generation means analysis of 5 genitors. Agronomie 14:249-257.

20. Epinat, C., Pitrat, M., and Bertrand, F. 1993. Genetic analysis of resistance of five melon lines to powdery mildews. Euphytica 65:135-144.

21. Foulongne, M., Pascal, T., Pfeiffer, F., and Kervella, J. 2003. QTLs for powdery mildew resistance in peach $\times$ Prunus davidiana crosses: Consistency across generations and environments. Mol. Breed. 12:33-50.

22. Gallais, A. 1990. Théorie de la Sélection en Amélioration des Plantes. Masson, Paris, France.

23. Geffroy, V., Sevignac, M., Oliveira, J. C. F. D., Fouilloux, G., Skroch, P., Thoquet, P., Gepts, P., Langin, T., and Dron, M. 2000. Inheritance of partial resistance against Colletotrichum lindemuthianum in Phaseolus vulgaris and co-localization of quantitative trait loci with genes involved in specific resistance. Mol. Plant-Microbe Interact. 13:287-290.

24. Grigoriu, A. C., and Georgopoulos, S. G. 1984. Measurement of the degree and extent of metalaxyl resistance of Pseudoperonospora cubensis in Greece. ISPP Chemical Control Newsl. 4:12-14.

25. Grumet, R., Kabelka, E., McQueen, S., Wai, T., and Humphrey, R. 2000. Characterization of sources of resistance to the watermelon strain of Papaya ringspot virus in cucumber: Allelism and co-segregation with other potyvirus resistances. Theor. Appl. Genet. 101:463-472.

26. Hollomon, D. W., and Wheeler, I. E. 2002. Controlling powdery mildews with chemistry. Pages 249-255 in: The Powdery Mildews: A Comprehensive Treatise. R. R. Bélanger, W. R. Bushnell, A. J. Dik, and T. L. W. Carver, eds. The American Phytopathological Society, St. Paul, $\mathrm{MN}$.

27. Jagger, I. C., and Scott, G. W. 1937. Development of powdery mildew resistant cantaloupe No. 45. U.S. Dep. Agric. Circul. 441:1-5.

28. Katan, T. 1982. Cross resistance of metalaxyl-resistant Pseudoperonospora cubensis to other acylalanine fungicides. Can. J. Plant Pathol. 4:387-388.

29. Katzir, N., Danin-Poleg, Y., Tzuri, G., Karchi, Z., Lavi, U., and Cregan, P. B. 1996. Length polymorphism and homologies of microsatellites in several Cucurbitaceae species. Theor. Appl. Genet. 93:1282-1290.

30. Keller, M., Keller, B., Schachermayr, G., Winzeler, M., Schmid, J. E., Stamp, P., and Messner, M. M. 1999. Quantitative trait loci for resistance against powdery mildew in a segregating wheat $\times$ spelt population. Theor. Appl. Genet. 98:903-912.

31. Kenigsbuch, D., and Cohen, Y. 1989. Inheritance of resistance to downy mildew in a gynoecious muskmelon. Plant Dis. 73:994-996.

32. Kenigsbuch, D., and Cohen, Y. 1992. Inheritance of resistance to downy mildew in Cucumis melo PI 124112 and commonality of resistance genes with PI 124111F. Plant Dis. 76:615-617.

33. Kenigsbuch, D., and Cohen, Y. 1992. Inheritance and allelism of genes for resistance to races 1 and 2 of Sphaerotheca fuliginea in muskmelon. Plant Dis. 76:626-629.

34. Kosambi, D. D. 1944. The estimation of map distances from recombination values. Ann. Eugen. 12:172-175.

35. Kozma, P., Jr., and Dula, T. 2003. Inheritance of resistance to downy mildew and powdery mildew of hybrid family Muscadinia $\times V$. vinifera $\times$ V. amurensis $\times$ Franco-American hybrid. Acta Hortic. 603:457-463.

36. Lebeda, A. 1983. The genera and species spectrum of cucumber powdery mildew in Czechoslovakia. Phytopathol. Z. 108:71-79.

37. Lefebvre, V., and Palloix, A. 1996. Both epistatic and additive effects of QTLs involved in polygenic induced resistance to disease: A case study, the interaction pepper-Phytophthora capsici Leonian. Theor. Appl. Genet. 93:503-511.

38. Liao, C. Y., Wu, P., Hu, B., and Yi, K. K. 2001. Effects of genetic background and environment on QTLs and epistasis for rice (Oryza sativa L.) panicle number. Theor. Appl. Genet. 103:104-111.

39. McCreight, J. D. 2003. Genes for resistance to powdery mildew races 1 and 2 U.S. in melon PI 313970. Hortscience 38:591-594.

40. McCreight, J. D., Pitrat, M., Thomas, C. E., Kishaba, A. N., and Bohn, G. W. 1987. Powdery mildew resistance genes in muskmelon. J. Am. Soc. Hortic. Sci. 112:156-160.

41. Merdinoglu, D., Wiedemann-Merdinoglu, S., Coste, P., Dumas, V., Haetty, S., Butterlin, G., and Greif, C. 2003. Genetic analysis of downy mildew resistance derived from Muscadinia rotundifolia. Acta Hortic. 603:451-456.

42. Mohamed, Y. F., Bardin, M., Nicot, P. C., and Pitrat, M. 1995. Causal agents of powdery mildew of cucurbit in Sudan. Plant Dis. 79:634-636.

43. Nagy, G. S. 1976. Studies on powdery mildews of cucurbit. II. Life cycle and epidemiology of Erysiphe cichoracearum and Sphaerotheca fuliginea. Acta Phytopathol. Acad. Scientiarum Hung. 11:205-210.

44. Nicot, P. C., Bardin, M., and Dik, A. J. 2002. Basic methods for epidemiological studies of powdery mildew: Culture and preservation of isolates, production and delivery of inoculum, and disease assessment. Pages 83-99 in: The Powdery Mildews: A Comprehensive Treatise. R. R. Bélanger, W. R. Bushnell, A. J. Dik, and T. L. W. Carver, eds. The American Phytopathological Society, St. Paul, MN

45. Périn, C., Hagen, L. S., de Conto, V., Katzir, N., Danin-Poleg, Y., Portnoy, V., Baudracco-Arnas, S., Chadoeuf, J., Dogimont, C., and Pitrat, M. 2002. A reference map of Cucumis melo based on two recombinant inbred line populations. Theor. Appl. Genet. 104:1017-1034.

46. Pilet, M. L., Delourme, R., Foisset, N., and Renard, M. 1998. Identification of loci contributing to quantitative field resistance to blackleg disease, causal agent Leptosphaeria maculans (Desm.) Ces. et de Not., in winter rapeseed (Brassica napus L.). Theor. Appl. Genet. 96:23-30.

47. Pitrat, M., Blancard, D., and Epinat, C. 1989. A study on the variability of downy mildew and looking for sources of resistance in Cucumis melo. Pages 137-139 in: 'Cucurbitaceae 89'. C. E. Thomas, ed. Charleston, SC.

48. Pitrat, M., Dogimont, C., and Bardin, M. 1998. Resistance to fungal diseases of foliage in melon. Pages 167-173 in: Cucurbitaceae 98 Evaluation and Enhancement of Cucurbits Germplasm. J. D. McCreight, ed. American Society for Horticultural Science, Pacific Grove, CA.

49. Pitrat, M., Risser, G., Bertrand, F., Blancard, D., and Lecoq, H. 1996. Evaluation of a melon collection for diseases resistances. Pages 49-58 in: Cucurbits Towards 2000. VIth EUCARPIA Meeting on Cucurbit Genetics and Breeding. M. L. Gómez-Guillamon, C. Soria, J. Cuartezo, J. A. Torés, and R. Fernández-Muñoz, eds. Málaga, Spain

50. Pryor, T., and Ellis, J. G. 1993. The genetic complexity of fungal resistance genes in plants. Adv. Plant Pathol. 10:281-305.

51. Robertson, D. S. 1985. A possible technique for isolating genic DNA for quantitative traits in plants. J. Theor. Biol. 117:1-10.

52. Saghai-Maroof, M. A., Yue, Y. G., Xiang, Z. X., Stromberg, E. L., and Rufener, G. K. 1996. Identification of quantitative trait loci controlling resistance to gray leaf spot disease in maize. Theor. Appl. Genet. 93:539-546.

53. Schafer, J. F., and Roelfs, A. P. 1985. Estimates relationship between numbers of urediniospores of Puccinia graminis $\mathrm{f}$. sp. tritici and rates of occurrence of virulence. Phytopathology 75:749-750.

54. Sitterly, W. R. 1978. Powdery mildews of cucurbit. Pages 359-379 in: The Powdery Mildews. D. M. Spencer, ed. Academic Press, New York.

55. Taler, D., Galperin, M., Benjamin, I., Cohen, Y., and Kenigsbuch, D. 2004. Plant R genes that encode photorespiratory enzymes confer resistance against disease. Plant Cell 16:172-184.

56. Thomas, C. E. 1982. Resistance to downy mildew in Cucumis melo plant introductions and American cultivars. Plant Dis. 66:500-502.

57. Thomas, C. E. 1986. Downy and powdery mildew resistant muskmelon breeding line MR-1. Hortscience 21:329.

58. Thomas, C. E. 1988. Physiological specialization in downy and powdery mildews of cucurbit. Pages 51-56 in: 'Cucurbitaceae 88'. G. Risser and M. Pitrat, eds. Avignon, France.

59. Thomas, C. E. 1999. Additional evaluations of Cucumis melo L. germplasm for resistance to downy mildew. Hortscience 34:920-921.

60. Thomas, C. E., Inaba, T., and Cohen, Y. 1987. Physiological specialization in Pseudoperonospora cubensis. Phytopathology 77:1621-1624.

61. Thomas, C. E., and Jourdain, E. L. 1992. Evaluation of melon germplasm for resistance to downy mildew. Hortscience 27:434-436.

62. Vakalounakis, D. J., Klironomou, E., and Papadakis, A. 1994. Species spectrum, host range and distribution of powdery mildews on Cucurbitaceae in Crete. Plant Pathol. 43:813-818

63. van der Vossen, E. A. G., van der Voort, J. N. A. M., Kanyuka, K. Bendahmane, A., Sandbrink, H., Baulcombe, D. C., Bakker, J., Stiekema, W. J., and Klein-Lankhorst, R. M. 2000. Homologues of a single resistance-gene cluster in potato confer resistance to distinct pathogens: A virus and a nematode. Plant J. 23:567-576.

64. Zeng, Z. B. 1994. Precision mapping of quantitative trait loci. Genetics 136:1457-1468 